\section{Mowing Height Effects on Summer Turf Growth and Physiological Activities for Two Creeping Bentgrass Cultivars}

\author{
Xiaozhong Liu ${ }^{1}$ and Bingru Huang ${ }^{2}$ \\ Department of Plant Biology and Pathology, Rutgers University, New \\ Brunswick, NJ 08901
}

Additional index words. Agrostis palustris, photosynthesis, respiration, turf quality

\begin{abstract}
Low mowing increases ball roll distance on putting greens, but may affect growth and physiological responses to summer heat stress. The objective of this study was to examine whether the effect of mowing heights on turf summer performance was associated with changes in photosynthetic activities and respiration rate for two creeping bentgrass [Agrostis palustris (L.) Huds] cultivars, 'Crenshaw' and 'Penncross'. Both cultivars were grown under USGA-specification putting green conditions from 1997 to 1998. Grasses were mowed daily at a $3-\mathrm{mm}$ (low mowing) or 4-mm (high mowing) height. Turf quality, net photosynthesis rate $\left(P_{n}\right)$, and leaf photochemical efficiency $(\mathrm{Fv} / \mathrm{Fm}) \mathrm{de}$ clined, whereas respiration rate of whole plants, canopy minus air temperature, and soil temperatures increased under low mowing compared to those at the high mowing height. The decline or increase in those parameters under low mowing was more pronounced in summer than in spring or fall months. The results showed that turf quality was better at the 4-mm mowing height, especially during summer months. Better quality at the higher mowing height could be related to the maintenance of higher photosynthetic activities and lower respiration rate. Mowing at the lower height had more adverse effects on turf growth and photosynthetic capacity for 'Penncross' than 'Crenshaw', particularly during summer months.
\end{abstract}

Creeping bentgrass greens are currently mowed daily at about 4-mm height on many golf courses. Turf quality of low-mowed creeping bentgrass often declines during summer in warm climatic areas (Beard, 1997; Carrow, 1996). However, the average mowing height is decreasing as golfers demand fast putting surfaces. Reduced mowing height may increase the susceptibility of turfgrasses to environmental stresses, including heat stress (Beard, 1973; Beard and Daniel, 1965). Low mowing during the summer may be more detrimental for heat sensitive cultivars than heat tolerant ones.

Extensive research has found that lowering the mowing height reduces turf quality of creeping bentgrass (Beard, 1997; Carrow, 1996; Madison, 1960; Salaiz et al., 1995), but few studies have compared responses of cultivars differing in heat tolerance to low mowing. Root production and depth decreases as mowing height is lowered (Beard, 1973; Beard and Daniel, 1965; Krans and Beard, 1985; Salaiz et al., 1995). Lowering the mowing height reduces photosynthesis by removing large amounts of green leaves that otherwise are available for light interception (Hull, 1987; Krans and Beard, 1985). Lowmowed creeping bentgrass also has a lighter color than grass mowed at a higher height (Salaiz et al., 1995). However, under close mowing conditions, nonphotosynthesizing

Received for publication 28 Jan. 2002. Accepted for publication 26 June 2002.

${ }^{1}$ Former Graduate Research Assistant.

${ }^{2}$ Associate Professor. E-mail address: huang@ aesop.rutgers.edu tissues continue to respire. Carbon loss through respiration generally accounts for about half of the carbon fixed by photosynthesis in grasses and cereal crops and can exceed carbon fixation with increasing temperatures (Lambers, 1985). A positive balance of photosynthesis and respiration determines the availability of carbohydrates that serve as energy reserves and provide carbon skeletons for both catabolic and anabolic reactions. Carbohydrate availability affects plant survival under stressful conditions (Sisson, 1989).

The objectives of this study were to compare the effects of low mowing, particularly during summer months, on turf growth, photosynthesis and respiration for two creeping bentgrass cultivars, 'Penncross' and 'Crenshaw', which differ in heat tolerance; and to determine whether bentgrass quality decline under lower mowing heights is related to the alteration of photosynthetic capacity and respiration rate. Previous studies have shown that 'Crenshaw' is more heat tolerant than 'Penncross' (Huang et al., 1998a, 1998b). Understanding physiological factors involved in summer bentgrass decline under low mowing for cultivars differing in heat tolerance will help identify physiological traits that could be incorporated into breeding programs.

\section{Materials and Methods}

Cultivars and mowing treatments. "Crenshaw' and 'Penncross' were examined on a USGA-specification putting green at the Rocky Ford Turfgrass Research Center, Manhattan,
Kans. Each cultivar was seeded in 205-cm-wide $\times 735-\mathrm{cm}$-long plots at a rate of $76 \mathrm{~kg} \cdot \mathrm{ha}^{-1}$ in late Sept. 1996 on a USGA-specification putting green. The rootzone materials contained $80 \%$ sand and $20 \%$ peat moss, which had $3 \%$ organic matter and a $\mathrm{pH}$ value of 7.5. Two mowing heights were imposed on both cultivars from early May to late Oct. 1997 and 1998. Grasses were mowed at $3 \mathrm{~mm}$ (low mowing) or $4 \mathrm{~mm}$ (high mowing) for $6 \mathrm{~d}$ each week.

The experiment was conducted in 1997 and 1998. During the growing season from early May to late October, the turf was mowed daily, except Sundays, at either 3 or $4 \mathrm{~mm}$. During this period, the green was irrigated daily to replace $100 \%$ of the evapotranspiration rate of the previous day. Grasses were syringed (wetting turf canopy with a small amount of water) on hot summer days. The turf received total $\mathrm{N}$ $\left(\mathrm{NH}_{4}\right.$ and $\left.\mathrm{NO}_{2}\right)$ of $216 \mathrm{~kg} \cdot \mathrm{ha}^{-1}$, and $54 \mathrm{~kg} \cdot \mathrm{ha}^{-1}$ per year of $\mathrm{K}\left(\mathrm{K}_{2} \mathrm{O}\right)$ and $\mathrm{P}\left(\mathrm{P}_{2} \mathrm{O}_{5}\right)$ in 1997 and $238 \mathrm{~kg} \cdot \mathrm{ha}^{-1}$ of $\mathrm{N}$ and $60 \mathrm{~kg} \cdot \mathrm{ha}^{-1}$ of $\mathrm{K}$ and $\mathrm{P}$ in 1998 to maintain adequate soil nutrients. In both years, iprodione [3-(3,5-dichlorophenyl)$\mathrm{N}$-(1-methylethyl)-2,4,-dioxo-1-imidazolidinecarboxamide] was applied at $3.1 \mathrm{~kg} \cdot \mathrm{ha}^{-1}$ to control diseases (Sclerotinia homoeocarpa and Rhizoctonia solani) as a curative treatment as soon as initial symptoms were detected.

Measurements. Turf quality was evaluated visually as a combination of turf density, uniformity, and color, and rated on the scale of 0 ( worst $=$ dead turf) to 9 (best $=$ dense, uniform, green, and vigorous turf). Canopy characteristics, including normalized vegetation difference index (NVDI) and canopy color index (CI), were evaluated by measuring canopy reflectance at different wavelengths using a multispectral radiometer (CROPSCAN, Rochester, Minn.). Reflectances at $661 \mathrm{~nm}$ $\left(R_{661}\right)$ and $935 \mathrm{~nm}\left(\mathrm{R}_{935}\right)$ measured by positioning the radiometer over the turfgrass canopy were used to estimate NVDI and CI, where $\mathrm{NVDI}=\left(\mathrm{R}_{935}-\mathrm{R}_{661}\right) /\left(\mathrm{R}_{935}+\mathrm{R}_{661}\right)$ and $\mathrm{CI}=$ $1 / R_{661}$ (Hatfield et al., 1983). NVDI has been used to estimate leaf area index and green leaf biomass in various species, including wheat (Triticum aestivum L.) (Hatfield et al., 1983) and seashore paspalum (Paspalum vaginatum Swartz) ecotypes and hybrid bermudagrass (Cynodon dactylon L. x C. transvaalensis Burtt-Davy) (Trenholm et al., 1999). The reciprocal of $R_{661}\left(1 / R_{661}\right)$ was used to estimate canopy greenness.

Leaf photochemical efficiency was estimated by measuring the ratio of variable fluorescence $(\mathrm{Fv})$ to maximum fluorescence of chlorophyll (Fm) after leaves were exposed to the dark for 20 min using the Plant Efficiency Analyzer (Hansatech Instrument, Kings Lynn, England). The $\mathrm{Fv} / \mathrm{Fm}$ ratio indicates the integrity of the photosynthetic apparatus and has been used widely to estimate photochemical efficiency (Krause and Weis, 1991).

Rates of $\mathrm{CO}_{2}$ fixation and evolution per unit turf area were measured by enclosing the turf canopy in a transparent plexiglass chamber (10 $\mathrm{cm}$ diameter $\times 5 \mathrm{~cm}$ deep) attached to the LI-COR 6400 gas exchange system (LI-COR, Lincoln, Nebr.). Respiration rate (rate of $\mathrm{CO}_{2}$ evolution) of whole plants (shoots and roots) 
and soil $\left(\mathrm{R}_{\text {plant }+ \text { soil }}\right)$ and that of bare soil $\left(\mathrm{R}_{\text {soil }}\right)$ was measured in dark. Turf net photosynthetic rates $\left(\mathrm{P}_{\mathrm{n}}\right)$ was the sum of the rate of $\mathrm{CO}_{2}$ uptake and $R_{\text {soil }}$ measured from 10:00 to 16:00 HR on sunny days. Respiration rate of whole plants $\left(\mathrm{R}_{\text {plant }}\right)$ was determined by subtracting $\mathrm{R}_{\text {soil }}$ from that of $\left(R_{\text {plant }+ \text { soil }}\right)$, which was measured $2 \mathrm{~h}$ after sunset (Biscoe et al., 1975; Xu and Huang, 2000). The soil used to estimate soil respiration was an unplanted area within the grass plot isolated from grassed areas with a plastic tube $(10 \mathrm{~cm}$ diameter and $5 \mathrm{~cm}$ deep). This area of soil was subjected to the same irrigation, fertilizer, and fungicide programs as the grassed areas.

Soil temperature was monitored at 1-h intervals at 5,10 , and $15 \mathrm{~cm}$ from the soil surface using thermocouples and a CR-10 data logger (Campbell Scientific, Logan, Utah). Canopy minus air temperatures were measured directly with an infrared thermometer (Everst Interscience, Tustin, Calif.) that was positioned at $45^{\circ}$ and $\approx 30 \mathrm{~cm}$ from the canopy surface on clear sunny days from 1000 to $1200 \mathrm{HR}$.

Experimental design. The experiment was a completely randomized split-plot design with repeated measures (Snedecor and Cochran, 1980). Cultivars were the main plots and mowing heights were the subplots. Both cultivar and mowing height treatments were replicated three times in three randomly assigned plots. Measurements were made at various times to examine mowing effects and cultivar variations over time. Three measurements for each of the parameters described above (sub-samples) were made in each of the three replicated plots for each treatment. Effects of cultivar, mowing, time of measurements, and their interaction were determined using a single three-way of analysis of variance according to the general linear procedure of the Statistical Analysis System (SAS Institute, Cary, N.C.). Differences among treatment means were separated by Tukey's studentized multiple comparison test using the minimum significance difference (MSD) at the probability of 0.05 level.

\section{Results and Discussion}

The effects of mowing height and significant interactions between mowing height or cultivar and time of measurement were significant for all parameters, with an exception of nonsignificant effect of mowing height on the color index (Table 1). Cultivar effects were significant for NVDI, CI, and $\mathrm{R}_{\text {plant }}$, but not for turf quality, Pn, and Fv/Fm ratio. The interaction between mowing height and cultivar was significant for turf quality, $\mathrm{Pn}$, and Fv/Fm ratio, but not for the other parameters (Table 1).

Low mowing significantly reduced turf quality of both cultivars during most of the experimental period, beginning in late June in both 1997 and 1998 (Fig. 1). Turf quality declined to the lowest level in August and September in both years. Turf quality decline at low mowing was greater for heat-sensitive 'Penncross' than for heat-tolerant 'Crenshaw' during the summer months. Other studies also have reported decreased turf quality in creeping bentgrass with low mowing heights (Salaiz et
Table 1. Significance analysis for the effect of mowing heights, cultivar, time of measurements and the interactions on turf quality, vegetation index (NVDI), color index $(\mathrm{CI})$, canopy net photosynthetic rate $\left(\mathrm{P}_{\mathrm{n}}\right)$, photochemical efficiency $(\mathrm{Fv} / \mathrm{Fm})$, and whole-plant respiration rate $\left(\mathrm{R}_{\text {plant }}\right)$ in 1997 and 1998.

\begin{tabular}{lcccccc}
\hline & Quality & NVDI & CI & $\mathrm{P}_{\mathrm{n}}$ & $\mathrm{Fv} / \mathrm{Fm}$ & $\mathrm{R}_{\mathrm{plant}}$ \\
\hline Mowing (M) & $*$ & $*$ & $\mathrm{NS}$ & $* *$ & $*$ & $*$ \\
Time (T) & $*$ & $* *$ & $* *$ & $* *$ & $*$ & $* *$ \\
Cultivar (C) & $\mathrm{NS}$ & $*$ & $*$ & $\mathrm{NS}$ & $\mathrm{NS}$ & $*$ \\
$\mathrm{M} \times \mathrm{T}$ & $*$ & $* *$ & $* *$ & $* *$ & $*$ & $*$ \\
$\mathrm{C} \times \mathrm{M}$ & $*$ & $\mathrm{NS}$ & $\mathrm{NS}$ & $*$ & $*$ & $\mathrm{NS}$ \\
$\mathrm{C} \times \mathrm{T}$ & $*$ & $*$ & $*$ & $*$ & $*$ & $*$ \\
$\mathrm{M} \times \mathrm{T} \times \mathrm{C}$ & $*$ & $*$ & $*$ & $*$ & $*$ & $*$ \\
Ns, ${ }^{*}, * *$ Nonsignificant & or significant at $P=0.05$ and 0.01 , respectively.
\end{tabular}

al., 1995). Lowering the mowing height also reduced vegetation index for both cultivars most of the time in both years (Fig. 2). Mowing had no significant effect on turf color during most of the experimental period (Fig. 3). Canopy density and color are two major components of visual turf quality rating. Previous studies in other species suggest that ND is positively correlated with leaf area index and green leaf biomass (Hatfield et al., 1983; Trenholm et al., 1999). Our results suggest that lowering mowing height caused turf quality decline mainly by reducing the vegetation index or canopy density.

Declines in turf quality and growth under low mowing, particularly during summer months, could be related to the imbalance of photosynthesis and respiration. In both 1997 and 1998, turf $P_{n}$ of both cultivars decreased to the lowest level in August and September and was further reduced by low mowing (Fig. 4). The reductions in $P_{n}$ under low mowing were greater during July, August, and September than in May, June, and October for both cultivars. The $\mathrm{P}_{\mathrm{n}}$ was not significantly different between cultivars under high mowing height. Photochemical efficiency (Fv/Fm) of both cultivars showed a pattern similar to that of $\mathrm{P}_{\mathrm{n}}$ in response to mowing height (Fig. 5). This ratio reflects changes in the quantum yield of photochemistry of the photosynthesis system II. Vegetation index (Fig. 2) and Fv/Fm (Fig. 5) decreased at the 3-mm mowing height. The decline in $\mathrm{P}_{\mathrm{n}}$ at low mowing height could be
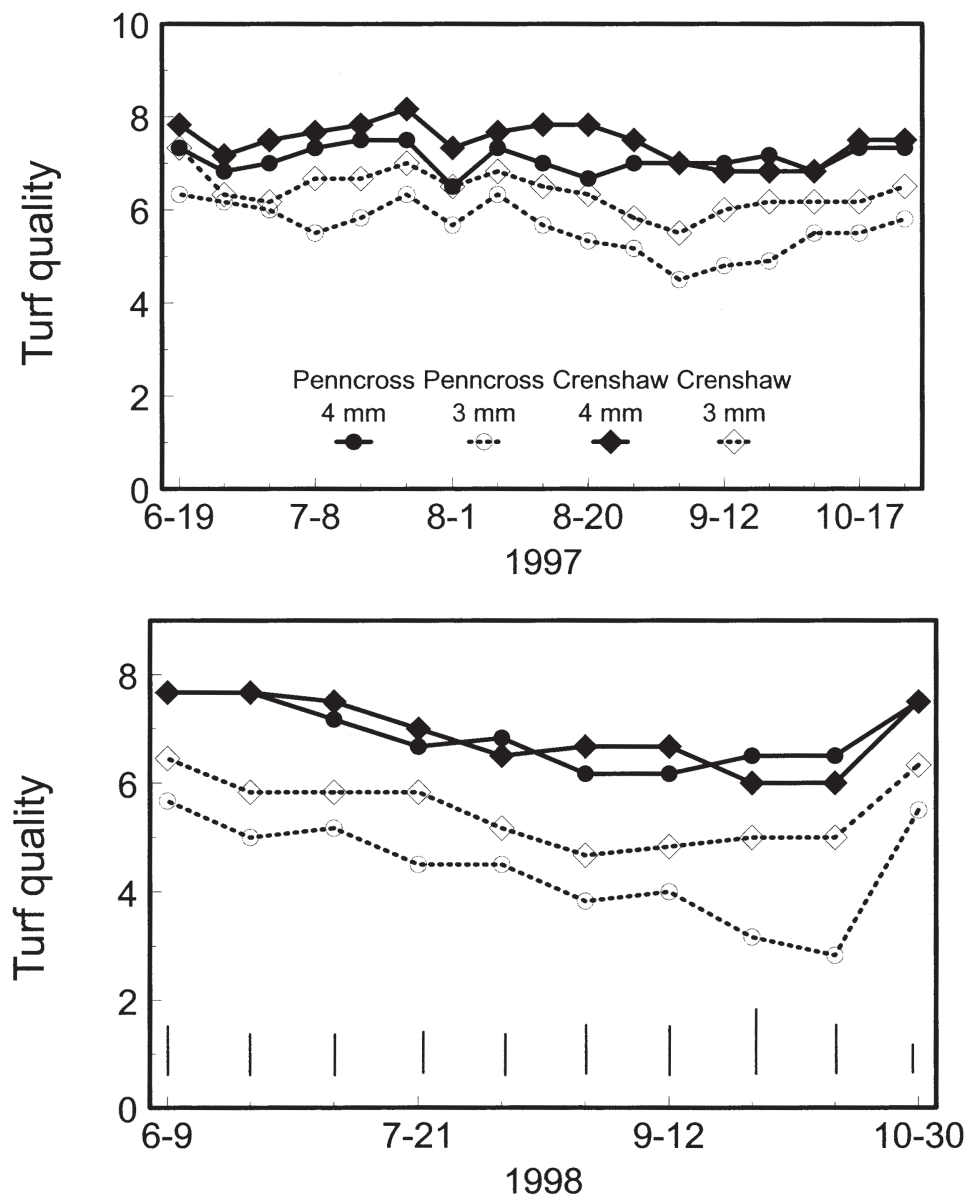

Fig. 1 Effect of mowing height on turf quality for 'Crenshaw' and 'Penncross' creeping bentgrass in 1997 and 1998. Vertical bars indicate minimum significance difference values $(P=0.05)$ for treatment comparisons on a given day. Turf quality was rated from 0 to 9 , where $0=$ dead turf and $9=$ best quality with green, and turgid leaves. 

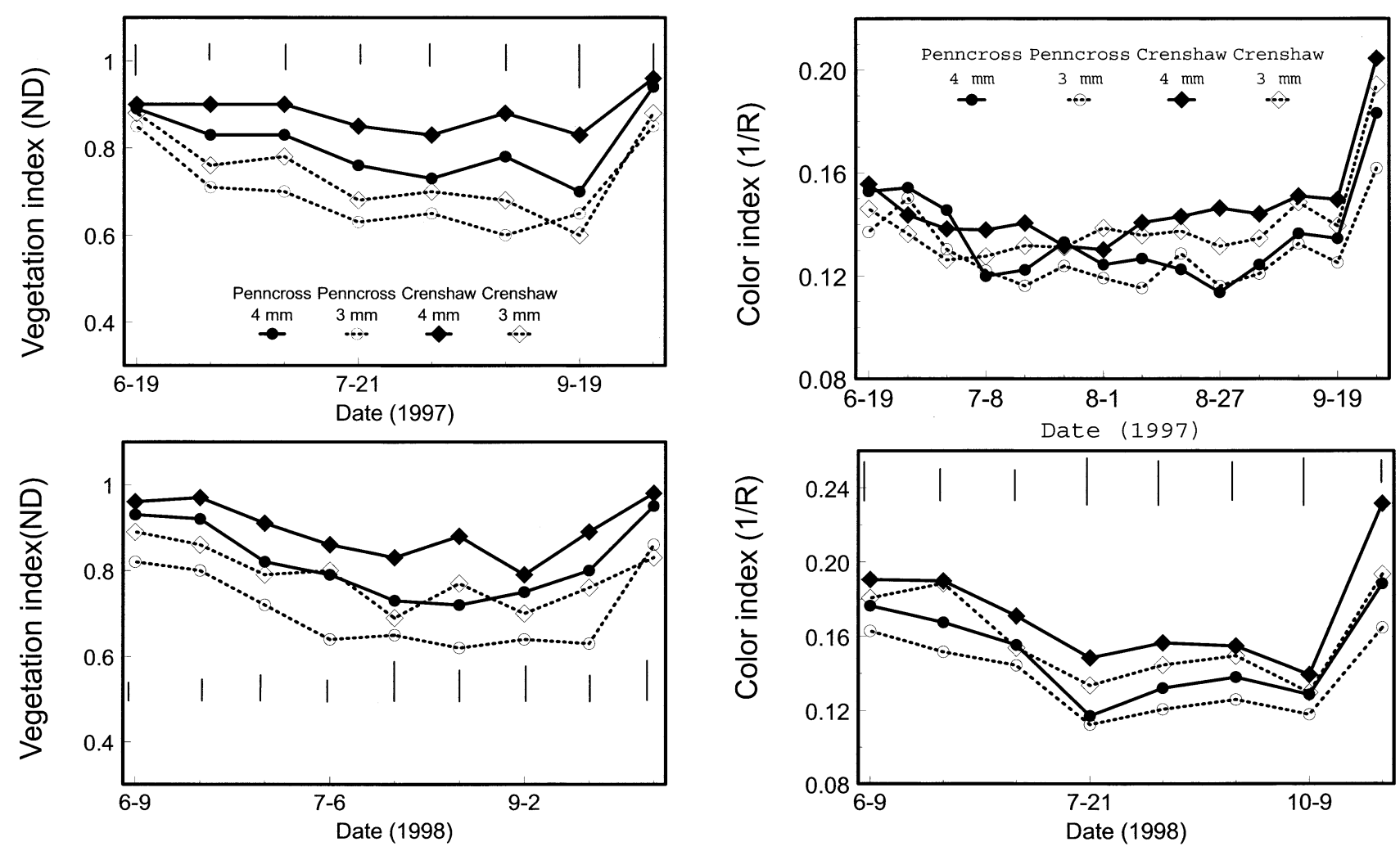

Fig. 2. Effect of mowing height on vegetation index (NVDI) for 'Crenshaw' and 'Penncross' creeping bentgrass in 1997 and 1998. Vertical bars indicate minimum significance difference values $(P=0.05)$ for treatment comparisons on a given day.

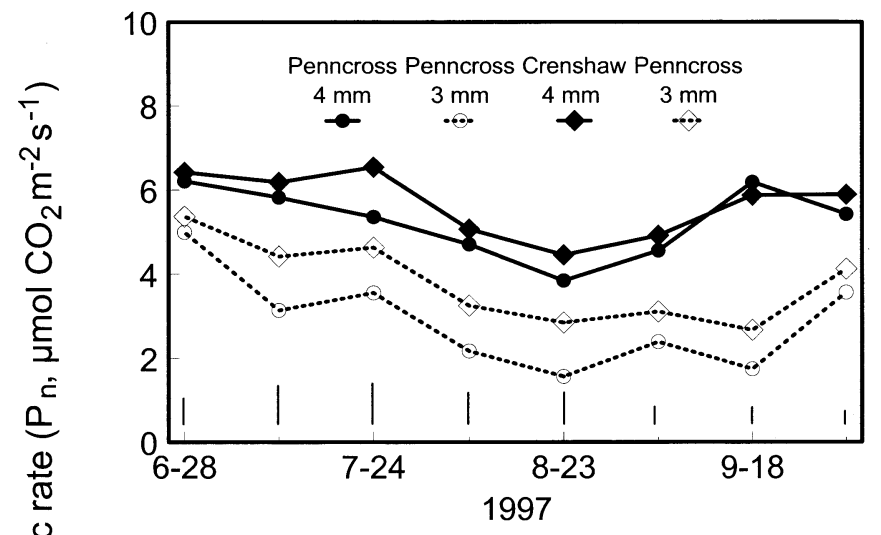

Fig. 3. Effect of mowing height on canopy color index $\left(1 / \mathrm{R}_{661}\right)$ for 'Crenshaw' and 'Penncross' creeping bentgrass in 1997 and 1998. Vertical bars indicate minimum significance difference values $(P=0.05)$ for treatment comparisons on a given day. Canopy color index is the reciprocal of the canopy reflectance at $661 \mathrm{~nm}(1 / \mathrm{R})$.
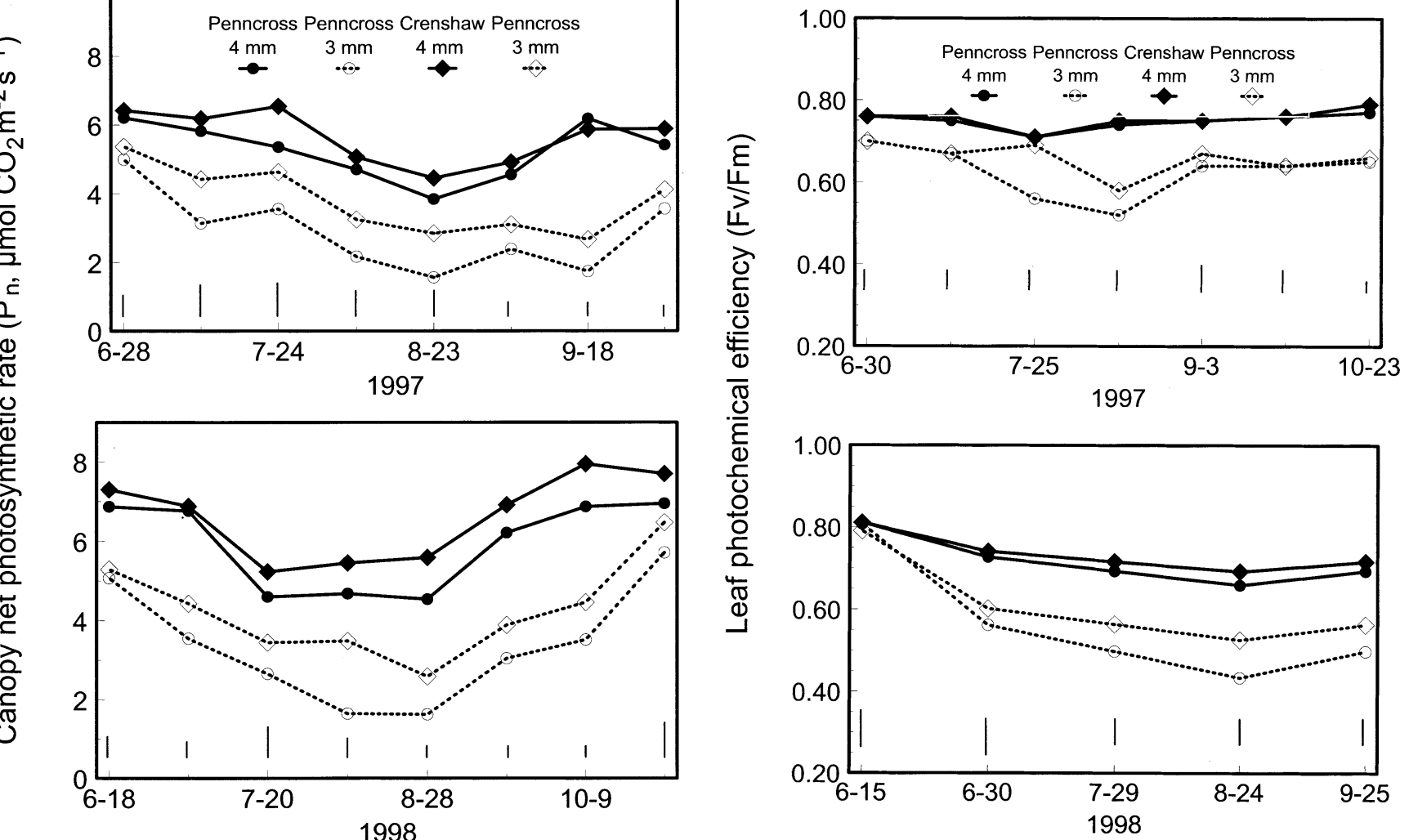

Fig. 4. Effects of mowing height on canopy net photosynthetic rate $\left(P_{n}\right)$ for 'Crenshaw' and 'Penncross' in 1997 and 1998. Vertical bars indicate minimum significance difference values $(P=0.05)$ for treatment comparisons on a given day. 


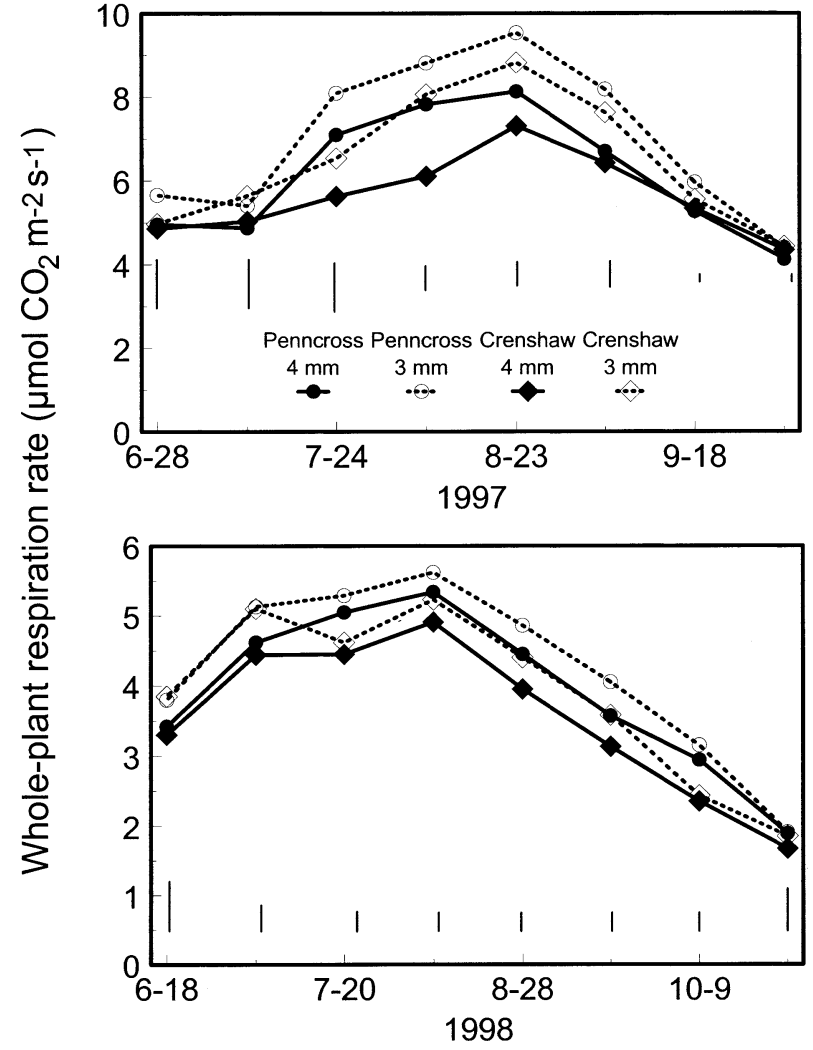

Fig. 6. Effect of mowing height on whole-plant respiration rate for 'Crenshaw' and 'Penncross' creeping bentgrass in 1997 and 1998. Vertical bars indicate minimum significance difference values $(P=0.05)$ for treatment comparisons on a given day. Respiration rate of whole plants $\left(\mathrm{R}_{\mathrm{plant}}\right)$ was determined by subtracting $\mathrm{R}_{\text {soil }}$ from that of $\left(\mathrm{R}_{\text {plant }}+\right.$ soil $)$. related to reduction of total leaf areas available for photosynthesis and to decreases in leaf photosynthetic efficiency. The decline in Fv/Fm under low mowing indicated that damage to the photosynthesis system II occurred.

Whole-plant respiration rate increased to the maximum level measured in August for both cultivars and in both years (Fig. 6). The response of respiration rate to mowing showed an increase pattern, opposite to that for $P_{n}$. In 1997 and 1998, respiration rate was significantly higher at the low mowing height than at the high mowing height during July and August for both cultivars. The higher respiration rate at the low mowing height may have been related to increases in canopy temperatures during summer months. Respiration is sensitive to temperature changes. The $\mathrm{Q}_{10}$ (the rate of change in a enzymatic reaction with a $10{ }^{\circ} \mathrm{C}$ change of temperature) for plants is $\approx 2$, which means the respiration rate doubles when temperature increase by $10^{\circ} \mathrm{C}$ (Salisbury, 1985). The highest levels of soil temperature were found in July and Aug. 1997 and Aug. and Sept. 1998 (data not shown). In both years, soil temperature averaged 2 to $3{ }^{\circ} \mathrm{C}$ higher under turf mowed at $3 \mathrm{~mm}$ compared to turf mowed at $4 \mathrm{~mm}$. There seemed to be a larger temperature difference at a depth of $5 \mathrm{~cm}\left(18\right.$ to $\left.38^{\circ} \mathrm{C}\right)$ relative to $10\left(16\right.$ to $\left.35^{\circ} \mathrm{C}\right)$ or $15 \mathrm{~cm}\left(15\right.$ to $\left.32^{\circ} \mathrm{C}\right)$. High soil temperature could result in high root respiration, which is a major contributor to whole-plant respiration (McCree, 1970). Furthermore, turf mowed at the 3-mm height had a higher canopy temperature
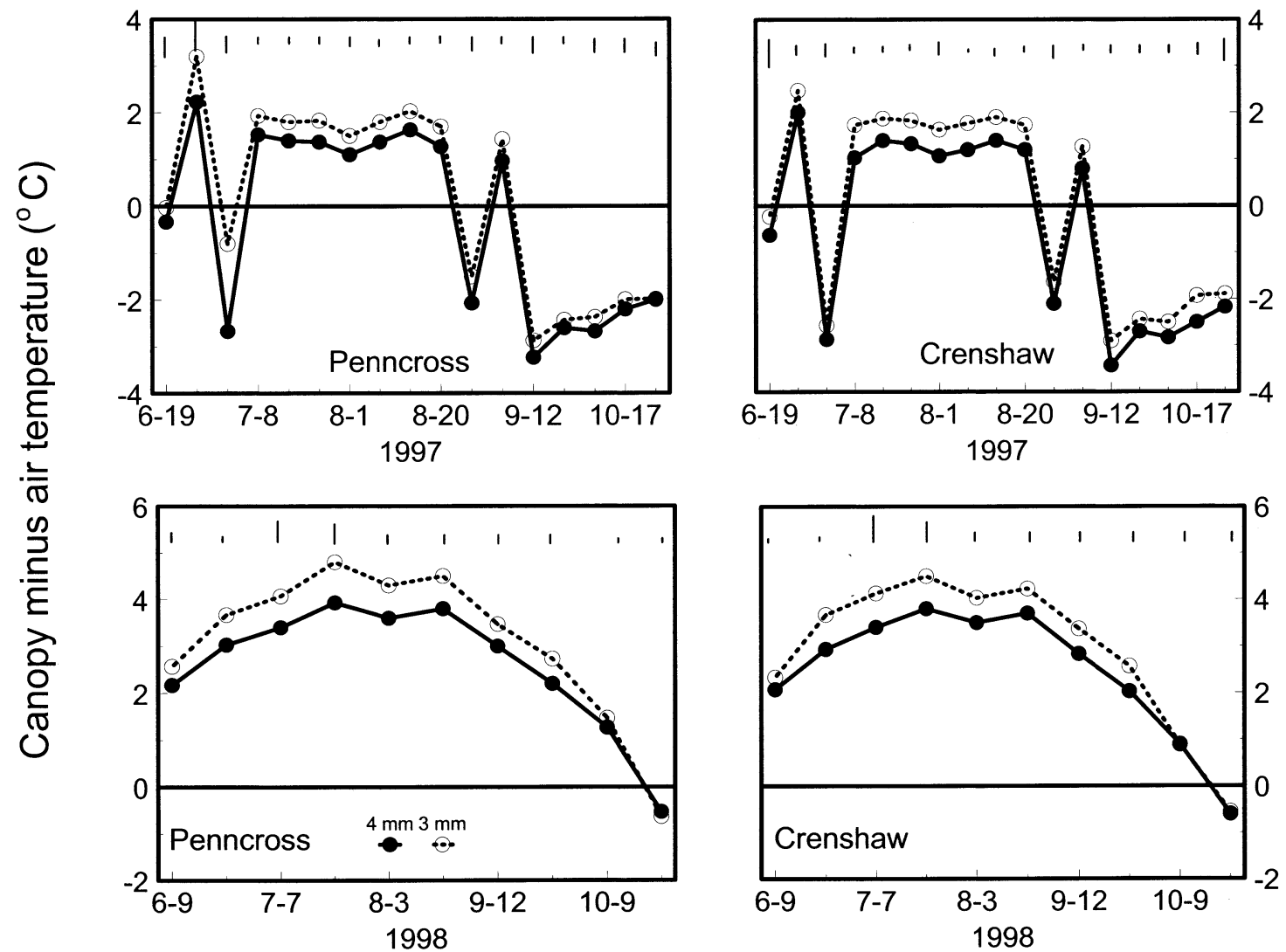

Fig. 7. Effect of mowing height on canopy minus air temperature for 'Crenshaw' and 'Penncross' creeping bentgrass in 1997 and 1998. Vertical bars indicate minimum significance difference values $(P=0.05)$ for treatment comparisons on a given day. 
than that mowed at the 4-mm height during summer months for both cultivars (Fig. 7). High canopy temperature can enhance the canopy respiration rate(Salisbury, 1985).

In summary, the results of this study demonstrated that turf quality and photosynthetic capacity declined with lowering mowing height, to a greater extent for heat-sensitive 'Penncross' than heat-tolerant 'Crenshaw'. Turf quality decline under low mowing height was attributed mainly to lower vegetation index. Decreases in canopy photosynthetic rate and increases in respiration rate likely contributed to lower turf quality under close mowing conditions, especially during summer months for the heat sensitive cultivar.

\section{Literature Cited}

Biscoe, P.V., R.K. Scott, and J.L. Monteith. 1975. Barley and its environment: III. Carbon budget of the stand. J. Appl. Ecol. 12:269-293.

Beard, J.B. 1973. Turfgrass: Science and culture. Prentice-Hall, Englewood Cliffs, N.J.

Beard, J.B. 1997. Dealing with heat stress on golf course turf. Golf Course Mgt. 65(7):54-59.

Beard, J.B. and W.H. Daniel. 1965. Effect of temperature and cutting on the growth of creeping bentgrass (Agrostis palustris Huds.) roots. Agron. J. 57:249-250.

Carrow, R.N. 1996. Summer decline of bentgrass greens. Golf Course Mgt. 64(6):51-56.

Hatfield, J.L., E.T. Kanemasu, G. Asrar, R.D Jackson, P.J. Pinter, Jr., R.J. Reginato, and S.B. Idso. 1983. Leaf area estimaters from spectral measurements over various planting dates of wheat. Intl. J. Remote Sens.

Huang, B., X. Liu, and J.D. Fry. 1998a. Shoot physiological responses to high temperature and poor soil aeration in creeping bentgrass. Crop Sci. 38:1858-1863.

Huang, B., X. Liu, and J.D. Fry. 1998b. Effects of high temperature and poor soil aeration on root growth and viability of creeping bentgrass. Crop Sci. 38:1618-1622.

Hull, R.J. 1987. Kentucky bluegrass photosynthate partitioning following scheduled mowing. J. Amer. Soc. Hort. Sci. 112:829-834.

Krans, J.V. and J.B. Beard. 1985. Effects of clipping on growth and physiology of 'Merion' Kentucky bluegrass. Crop Sci. 25:17-20.

Krause, G.H. and E. Weis. 1991. Chlorophyll fluorescence and photosynthesis: The basis. Ann. Rev. Plant Physiol. Plant Mol. Biol. 42:313-349.

Lambers, H. 1985. Respiration in intact plants and tissues. p. 418-473. Encyc. Plant Physiol. 18: 418-473.

Madison, J.H. 1960. The mowing of turfgrass. I. The effect of season, interval, and height of mowing on the growth of seaside bentgrass turf. Agron. J. 52:449-452.

McCree, K.J. 1970. An equation for the rate of respiration of white clover plants grown under controlled conditions, p. 221-229. In: I. Setlik (ed.). Proc BIP/PPTech. Mtg., Trebon. Prediction and measurement of photosynthetic productivity. PUDOC, Wageningen, The Netherlands.

Salaiz, T.A., G.L. Horst and R.C. Shearman. 1995. Mowing height and vertical mowing frequency effects on putting green quality. Crop Sci. 35: $1422-1425$.

Salisbury, F.B. 1985. Plant physiology. 3rd ed. Wadsworth Publ. Co., Belmont, Calif.

Sisson, W.B. 1989. Carbon balance of Panicum coloratum during drought and non-drought in the Northern Chihuahuan desert. J. Ecol. 77: 799-810.

Snedecor, G.W. and W.G. Cochran. 1980. Statistical methods. 7th ed. Iowa State Univ. Press, Ames.

Trenholm, L.E., R.N. Carrow, and R.R. Duncan. 1999. Relationship of multispectral radiometry data to qualitative data in turfgrass research. Crop Sci. 39:763-769.

Xu, Q. and B. Huang. 2000. Effects of differential air and soil temperature on carbohydrate metabolism in creeping bentgrass. Crop Sci. 40: 1368-1374. 